\title{
Rural-Urban Migration and the Growth of Informal Settlements: A Socio-Ecological System Conceptualization with Insights Through a "Water Lens"
}

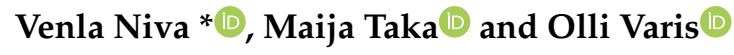 \\ Water and Development Research Group, Aalto University, P.O. Box 11000, FI-00076 Espoo, Finland; \\ maija.taka@aalto.fi (M.T.); olli.varis@aalto.fi (O.V.) \\ * Correspondence: venla.niva@aalto.fi
}

Received: 29 May 2019; Accepted: 21 June 2019; Published: 25 June 2019

check for updates

\begin{abstract}
Informal settlements i.e., slums emerge from the interplay of multidimensional factors related to urbanization and sustainability. While the contribution of urban factors is well understood, the role of external drivers, such as uncontrolled migration to urban areas, is rarely addressed in research or policy-making. This study develops a novel conceptualization of slums by reviewing the pushing and pulling factors of migration and their contribution to informal settlements through 1) a socio-ecological system approach and 2) the concept of adaptive capacity. Further, it advances the discussion around synergistic and coherent policy-making in the urban context by reviewing three urban agendas and further using water as a case with the concept of cross-cutting domains. We show that the emergence of urban challenges can, and should be, linked to the root causes of flows into urban areas. Understanding these linkages through a socio-ecological system framework opens a window for knowledge-based policy development and addressing the question of how to avoid unsustainable urban development. Urbanization is one of the phenomena where the excessive complexity and dimensions of problems should not hamper action but instead, actions should be encouraged and enabled with synergistic and integrative pathways for sustainable urban development.
\end{abstract}

Keywords: rural-urban migration; adaptive capacity; socio-ecological system; cross-cutting domains; human-nature systems; sustainable urban development; urban agenda

\section{Introduction}

The emergence of informal settlements i.e., slums is among the most apparent challenges in our rapidly urbanizing world. Despite the numerous slum upgrading attempts around the world, informal settlements remain a pervasive negative side-effect of urbanization: currently over half of urban population in lower income countries [1] and a total of 863 million people globally [2] accommodate in informal settlements. By definition, these inhabitants are exposed to numerous hazards and vulnerabilities given the extremely dense population and lack of secured tenure, safe and clean living environment, and access to the most basic services such as clean water, sanitation and health care $[3,4]$. Notably, these are all defined as universal human rights and included in United Nations' Sustainable Development Goals, indicating severe deficiencies in sustainable development $[5,6]$.

The drivers behind the emergence of informal settlements are manifold and interlinked to the complicated socio-economic-technical networks of urbanization and sustainability. The development of an informal settlement stems from both rapid population growth in poor urban areas and migration from rural to urban areas, which are massive trends in many parts of the world. In fact, poor urban settlements often function as "waiting rooms" for arriving migrants in low-income countries, [4,7-10]. 
Recent political unrest, uncertainties in global economies and diverging environmental extremes are adding weight to the global migration phenomena. Given these developments, we see that informal settlements are likely to be a seed for new human-related challenges.

Hence, there is an urgent need to comprehend the complex connection between rural-urban migration and unsustainable urban development, of which the growth of informal settlements can be seen as a good example. It is clear that urban issues are fed by interactions from the surrounding areas [11], highlighting the importance to step out of the "urban box" and extend the boundaries of analyses, both thematically and spatially. Moreover, despite studies discovering the pushing and pulling factors of migration in isolation, they have rarely taken a stand on the sustainability of migration nor have they questioned where migrants end up and why. Further, even though migration may function as an adaptation method against vulnerabilities, people are as likely to migrate into vulnerable environments (such as informal settlements) [12]. These issues cripple policy-making and practitioners face immense challenges in coping and mitigating the accelerating rural-urban migration and subsequent growing informal settlements in many parts of the world. For instance, despite global development agendas, such as the Sustainable Development Goals (SDGs) and the New Urban Agenda (NUA) point out slum upgrading and comprehensiveness as focal points of sustainable development $[13,14]$, it remains unclear how migration and the emergence of informal settlements are coupled in these agendas.

On these grounds, we argue that it is de rigueur to create approaches that systemically conceptualize the emergence of informal settlements as part of a larger system and assist multilevel policy-making in "connecting the dots" between different sectors contributing to urban issues. This study aims to extend the knowledge on these fronts through two objectives.

Firstly, we produce a novel conceptualization from the viewpoint of complex socio-ecological systems (SES), and the concept of adaptive capacity (AC) (See Materials and Methods). We hypothesize that the emergence of informal settlements manifests low AC across the root causes of migration. Further, we assume that $\mathrm{AC}$, and the lack thereof, reflect rural and urban conditions that push people to migrate and simultaneously pull migrants to settle in informal areas. Our conceptualization is based on a narrative literature review following our hypothesis. We classify pushing and pulling factors as generic or specific capacities and explore their interplay as a driver behind informal settlements.

Secondly, we scrutinize the status quo and needs of improvement for urban development agendas in terms of systemic policy-making. We review three central initiatives by United Nations (UN) to assess the status quo of urban agendas (New Urban Agenda (NUA), New Urban Policies (NUP), and Sustainable Development Goals (SDG)) in terms of systemic and sustainable policy-making. For improving systemic and coherent urban policy-making, we propose the adoption of cross-cutting domains. Water sector is presented as an example of one cross-cutting domain through the systematic "in All Policies" approach [15] (See Materials and Methods). Water is a cross-cutting factor and thus useful for sustainable development (such as migration) as it is fundamental to sustainability of key life-supporting functions and human survival and well-being [16]. Additionally, water has a critical role in supporting other development dimensions, such as equality, health, and inclusive cities [17]. The water sector has a critical cross-cutting role in sustainability and similar problematics regarding multi-dimensionality and complexity [18].

\section{Materials and Methods}

\subsection{Narrative Literature Review}

We analyze scientific literature, including peer-reviewed articles and handbooks, as well as reports, policy documents and working papers acquired through search engines and scientific databases such as Scopus, Web of Science and Google Scholar. Furthermore, an online search was conducted to identify relevant literature regarding urban and development policies and integrated governance approaches. 
The selection of surveyed publications showed that there are no studies approaching slums according to our hypothesis of adaptive capacity. Thus, rather than producing a quantitative meta-analysis, we aim to comprehend and reorganize current literature regarding complex urban human-nature systems and the drivers behind slums. To produce the conceptualization, we conduct an unsystematic narrative review, which is used to produce concise overviews of topics and to encourage discussion among readers [19]. Our review classifies pushing and pulling factors as generic or specific capacities and explored their interplay as a driver behind informal settlements.

\subsection{Theoretical Framework: Socio-Ecological Systems}

We base our approach on the concepts of complex socio-ecological urban systems (SES) and adaptive capacity (AC) [20-24]. SES is one of the most popular analytical approaches to complex systems in climate change, global environmental change and sustainability scholarships, as it provides a framework for exploring the interplay of social, political, economic and environmental factors within societal and ecological subsystems $[20-23,25,26]$. According to SES, urban areas emerge from the interaction between socio-economic-technical and ecological subsystems, and metabolism of resources, energy, policies and institutions [20-24,27-32]. Here, we adopt SES for a rural-urban context. Our approach is framed by rural and urban dimensions, including socio-economic and ecological subsystems, connected by rural-urban migration as the key interaction.

The sustainability of these interactions depends on adaptive capacity (AC) [33]. In general, $\mathrm{AC}$ can be seen as a link between the concepts of resilience and vulnerability and respective social and environmental dimensions of coupled human-nature systems [24]. Smit and Wandel [34] include adaptive capacity in "broader forces, drivers or determinants", which outline system vulnerability [34,35]. According to Eakin et al., the concept of AC can be framed as the interplay of general and specific capacities, i.e., the "basic human development needs" and skills that are vital for coping with known hazards (Figure 1) [33]. This further reflects the balance between social and environmental dimensions of socio-ecological systems [24]. Generic and specific capacities can be identified at both system-levels representing "broader societal institutional arrangements", such as governance and fundamental human development, and individual level, in terms of education or health, for instance [33] (Figure 1). The society-individual division is needed to assess cross-scale interaction and to create more detailed information for policy and practice [33]. The concept provides a prominent platform for hypothesizing that the emergence of informal settlements manifests low adaptive capacity across the root causes of migration. We hypothesize that the interplay of different generic and specific capacities, and the lack thereof, reflect individual and system-level rural and urban conditions which push people to migrate, yet on the other hand pulls migrants to settle in informal areas.

\subsection{Water in All Policies}

The water sector has experienced the need to develop various integrative and systemic approaches for policy-making in order to synchronize across different socio-economic and environmental sectors related to water (see e.g., Lenton and Muller [36] and Hoff [37]). In addition to the importance of its own, it is also part of various other sectors, such as environment, health, and infrastructure [15]. We chose the "in all policies", one of the most influential integrative management approach [15], to provide a prominent framework for creating systemic policies by screening all relevant sectors and components through a selected thematic "lens", such as health, energy or water [15,38,39]. We see that such approach has great potential for knowledge-based policy development. The World Health Organization (WHO) has used "Health in All Policies" approach for coherent framework to be adapted at several scales of decision-making from national to supranational [40]. The approach improves accountability of policymakers at all levels, concentrating on both the lens-related determinants and consequences [40]. Here the "Water in All Policies" approach will utilize the matrix approach of general 
and specific together with individual and system-level capacities to explore the role and potential of water in sustainable migration and urban development (Figure 1).

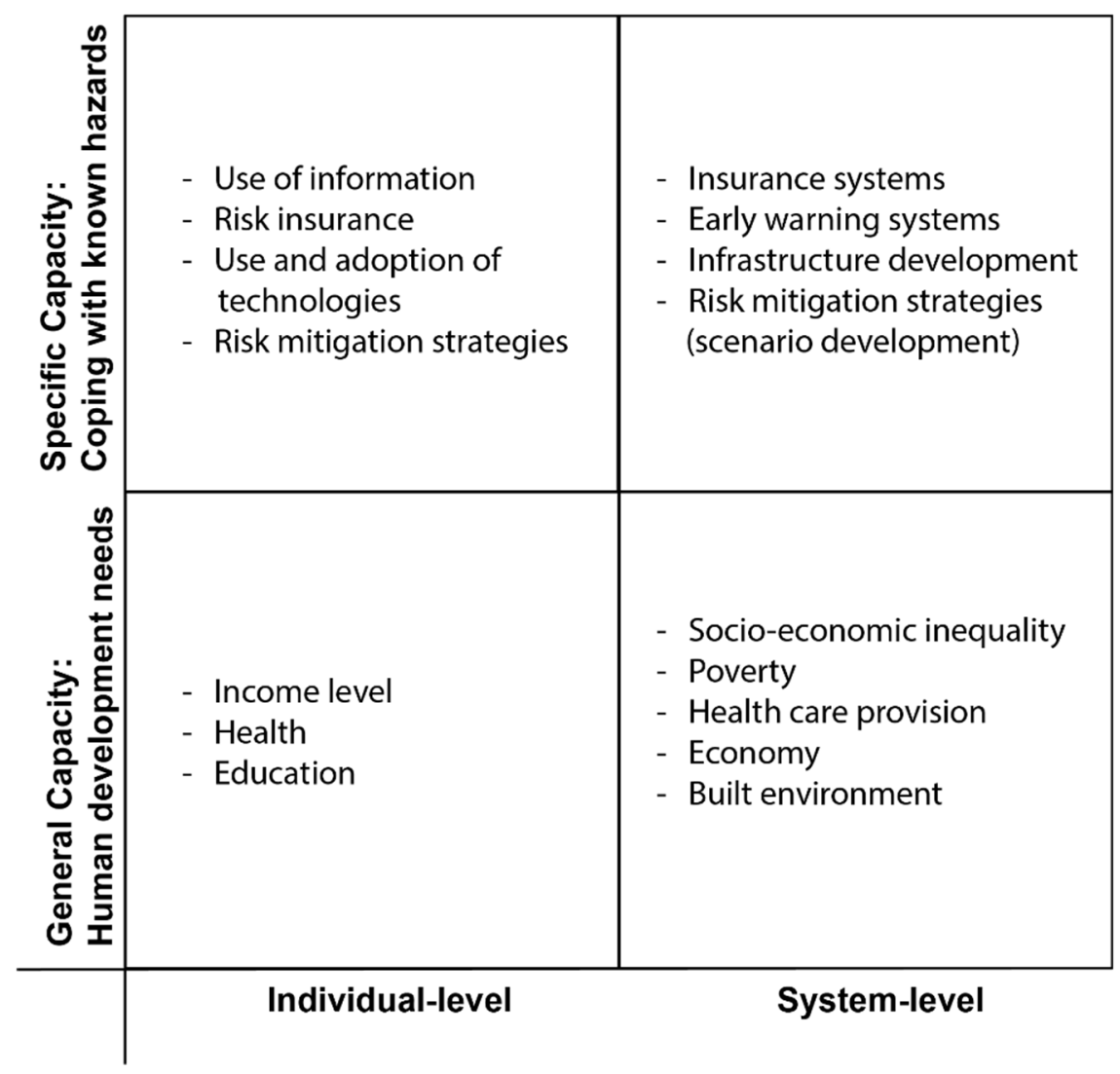

Figure 1. Examples of generic and specific capacities at individual and system levels. Adopted from Eakin et al. [33].

\section{Informal Settlements as a Manifestation of Low Adaptive Capacity in SES}

Rural outmigration is oftentimes framed in biasedly as an effective adaptation method for tackling many rural deficiencies that push people to move [12]. While this angle of literature examines migration as a manifestation of high individual capability, it neglects the paradoxality of such adaptation pathway: migration to urban centers might function as an adaptation method against socio-economic and environmental deprivation in rural areas, yet in Asia and Africa, many rural people looking for better life prospects end up in poor and vulnerable urban areas [41,42].

The sustainability of rural-urban migration as an adaptation pathway depends on the combination of generic and specific capacities embedded in the system [33] (Figure 1). In this section, we conceptualize the connection between rural-urban migration and the emergence of slums based on our hypothesis. We argue that low adaptive capacity across the root causes of migration, i.e., the interplay of different generic and specific capacities, and the lack thereof, reflect rural and urban conditions, which push people to migrate, yet on the other hand pulls migrants to settle in informal areas (Figure 2). Generic and specific capacities illustrate the elements of human development as well as specific skills required in a certain context at individual and system levels (Figure 1). The imbalance within the interplay of these capacities produces unsustainable outcomes, such as safety paradoxes and poverty traps (Figure 3), which manifest many characteristics of vulnerable informal settlements. 


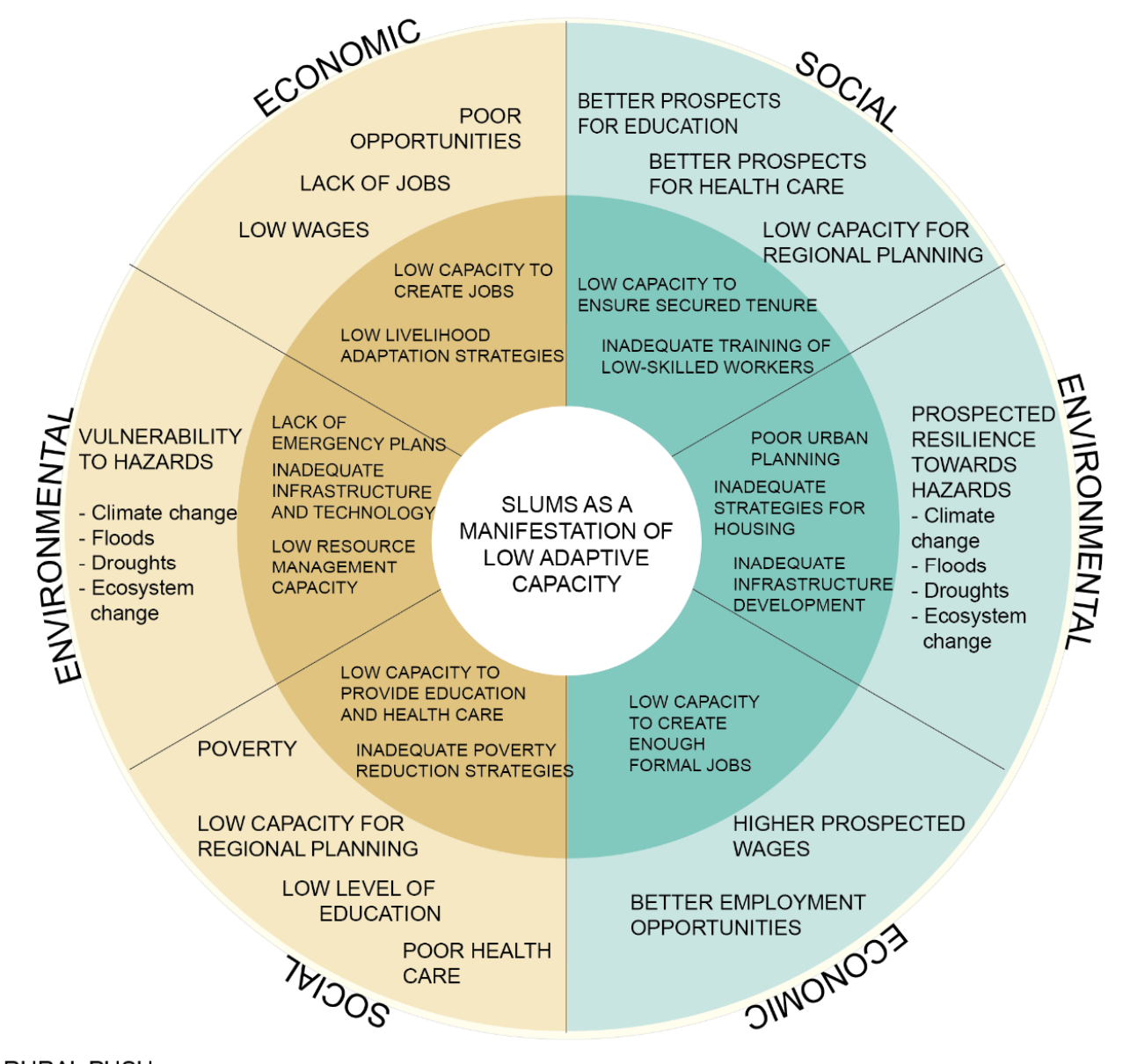

RURAL PUSH

URBAN PULL

$\begin{array}{ll}\text { GENERIC } & \text { SPECIFIC } \\ \text { CAPACITY } & \text { CAPACITY }\end{array}$

Figure 2. Schematic illustration of the emergence of informal settlements as a manifestation of low adaptive capacity within a rural-urban SES. The left and right sides of the outmost circle represent factors of generic capacities as rural push and urban pull. The middle circle illustrates the lack of specific capacities required to address vulnerabilities in the outmost circle.

\subsection{Generic Capacities}

Based on the literature, we can synthesize that many pushing and pulling factors of migration reflect a rural-urban gap regarding the level of sustainable development (Figure 2). Pushing factors portray rural vulnerability, caused by the lack of generic individual and system-level capacities. Rural-urban gap regarding income, level of health care, education and provision of basic services [33,34,43] as well as availability of vacancies are widely known as two of the prime root causes behind migration [44-47]. Industrialization [48,49], mechanization of agriculture [45] and the overall shift from agrarian to manufacturing and export industry, especially in the low-income countries in Asia and Africa [45,50] has widened the rural-urban income-gap.

On the urban side, pulling factors reflect higher prospected resilience and generic capacity including better prospects for education, health care, employment and higher wages (Figure 2) [50,51]. However, it is typical that destination areas have low system-level generic capacity to provide jobs and education required in the formal job markets [52]. Uneducated individuals from rural areas are under a risk of not finding suitable formal employment or education [53], and hence under a risk of marginalization and getting trapped in urban vulnerability. The rural-urban gap is further exacerbated 
and maintained by weak regional planning over the rural-urban continuum, weakening linkages and inter-connections between these areas [54].

\begin{tabular}{|c|c|c|}
\hline 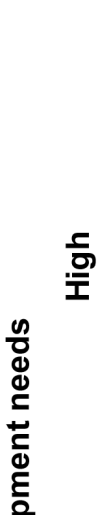 & $\begin{array}{l}\text { "Safe development paradox" } \\
\text { - High general assets } \\
\text { (education, income level, } \\
\text { health care; both individual } \\
\text { and system level) } \\
\text { - "Fail safe" development } \\
\text { plans } \\
\text { - Low capacity for risk } \\
\text { management } \\
\text { - Increased local } \\
\text { vulnerabilities } \\
\text { Migration into slums }\end{array}$ & $\begin{array}{l}\text { "Sustainable adaptation" } \\
\text { - High general assets } \\
\text { (individual and system level) } \\
\text { - High risk management } \\
\text { capacity } \\
\text { - Balance between short-term } \\
\text { and long-term development } \\
\text { (both individuals and } \\
\text { system-level) } \\
\text { Sustainable migration }\end{array}$ \\
\hline 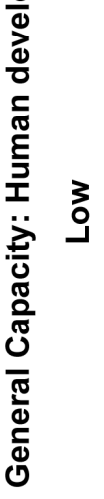 & $\begin{array}{l}\text { "Poverty trap" } \\
\text { - Chronic vulnerability } \\
\text { - Low human development } \\
\text { - Inability to cope with chronic } \\
\text { vulnerability or acute stress } \\
\text { (both individual and } \\
\text { system-level } \\
\text { Trapped populations } \\
\text { in poor rural and } \\
\text { urban areas }\end{array}$ & $\begin{array}{l}\text { "Safety first" } \\
\text { - Poor general assets } \\
\text { - Short-term security prioritizec } \\
\text { over long-term development } \\
\text { - Weak government level } \\
\text { support to build generic } \\
\text { capacities }\end{array}$ \\
\hline
\end{tabular}

Figure 3. Capacities matrix illustrates the interplay of generic and specific capacities. Each quadrant illustrates one possible migration outcome. Matrix modified from Eakin et al. [33].

\subsection{Specific Capacities}

Specific capacities illustrate skills and tools for human to cope with particular challenges (Figure 1). On the pushing side, use of social connections and first-hand information on employment and accommodation opportunities are pivotal specific individual skills that shape migration-decisions $[50,51]$. Furthermore, climate forecasting, livelihood diversification and building of protective infrastructure are examples of specific strategies that are vital for coping with short and long-term environmental hazards, which may lead to migration [55].

On the urban side, low specific system-wide capacity of urban government for "strategic planning and intervention" and complex multi-sectoral development regarding in-migration challenge sustainability in rapidly growing cities [56,57]. Specifically, the "competence, capacity and accountability" of a government to manage sudden and unpredictable flows of migration has more impact on the growth of informal settlements than urban population growth and migration, per se $[9,58]$. Meanwhile, many specific institutional and legislative frameworks, such as "no forced eviction policies", proposed by national and local governments exclude informal settlements, exacerbating vulnerability and marginalization [3].

\subsection{Balance within Adaptive Capacity}

We note that a balance between specific and generic capacities in a hypothesized rural-urban system is key when pursuing sustainable development and coping with particular risks at the same 
time (Figure 3). While migration is often framed as an adaptation method, we argue, it is sustainable only when the capacity for both human development and risk strategies is sufficiently high (Sustainable Adaptation in Figure 3).

For instance, in case where generic capacity is low, we can see that migration reflects a specific individual adaptation strategy against low generic development level in rural areas. However, low generic capacity of the destination area produces high risk migration into informal settlements due to a mismatch between rural expectations and urban reality (Safety First in Figure 3). In other words, people move when the gains of moving exceeds the ones of staying [59]. Migration into vulnerable urban areas can reflect decision-making patterns in which hopes for high gains are coupled with unknown outcomes and probability for high losses [59-61].

Another example of the rural-urban mismatch is represented by the "safe development paradox" (Figure 3) in which low system-level specific capacity to absorb arriving migrants depresses the high assets of migrants. We see that these two adaptation pathways highlight the importance to balance between individual and system-level capacities. The dynamics behind "poverty traps" (Figure 3) portrays an example of a vicious cycle in which general vulnerability from individual to system level is maintained by low human development and the ability to cope with specific stressors.

\section{Towards Systemic Urban Policy-Making}

\subsection{Connecting Informal Settlements and Migration Through Adaptive Capacity}

The growth of cities and their informal urban settlements are increasingly acknowledged as hot spots in global urban agendas. However, urban policies are criticized for missing the big picture and systemic view to urban issues [53]. Despite the fact that the proportion of global urban slum population decreased from $28.4 \%$ to $22.8 \%$ from 2000 to 2014, the actual number of people living in slums increased by 76 million [62]. We see that the UN is a global actor leading the discussion on the rising development problems, and taking actions to tackle these key challenges facing humanity. Therefore, we review next the UN's central development initiatives. Sustainable Development Goals (SDGs) include urban development as a piece of the complex puzzle of sustainability [13], whereas New Urban Agenda (NUA) concentrates on sustainable urbanization [14]. Finally, New Urban Policies (NUP) is a national level attempt for sustainability in urbanization and migration [42].

Agenda 2030 and SDGs are an ensemble of 17 overarching goals and 169 targets that succeeds the UN's Millennium Development Goals (2000-2015), aiming to transform people, the planet and prosperity to sustainability by 2030 [62]. The SDGs are balancing multiple dimensions of sustainable development, all of which should be considered in studies of various actors' dynamics [63]. The urban goal SDG11 is focused to "make cities and human settlements inclusive, safe, resilient and sustainable" $[13,14,42]$. Most of its ten targets, including one solely focused on slums, reflect the lack of generic capacities associated with urban challenges.

The New Urban Agenda recognizes the leading role of national governments in achieving their main goal of sustainable cities and human settlements for all [14]. Complementing the SDGs, NUA recognizes slums and informal settlements in the centre of complex urban issues, and considers slum upgrading programmes the predominant approach for enhancing the lives of slums dwellers in cities [14]. The slum upgrading and prevention programmes address a range of slum-related generic capacities as we conceptualized in the previous section. To create strategic interventions for managing sudden and unpredictable flows of migration [9,56-58], the agenda aims to incorporate systemic approaches for tackling urban challenges by proposing a paradigm shift towards a more holistic view on urban issues. Understanding the "fundamental drivers of change ... with strategies that go beyond physical and environmental improvements ... into social, economic, cultural and political dimensions" [14] are considered as means for such transformation.

NUA identifies NUP as one of the key tenets for achieving sustainability [14]. NUPs complement the sub-national urban policies through promoted "urban-rural partnership" and regional planning [54], 
and further aim to support governments to implement and monitor global agendas [42]. In line with the SDGs and NUA, informal settlements are acknowledged as central issues also in NUPs in many low-income countries [42]. These challenges are addressed by prioritizing human development through in-situ upgrading, which is considered the current "best practice" to tackle with slums [64]. NUPs also identify rapid urbanization. The related growth of informal settlements is featured as a key challenge in Asia, the Pacific, and in the Arab States [42].

While the need for holistic approaches is acknowledged and promoted in all three initiatives (Table 1), the inclusion of slums in the formal urban and rural-urban pattern appears to be missing on practical level. While the SDG11 targets cover a range of generic urban development challenges, we note that little emphasis is given for specific strategies on how to cope with emerging urban challenges. Accordingly, the NUA has been criticized for providing guidance on how to treat the adverse effects of urbanization, but not to how to avoid them $[65,66]$; the NUPs appear to lack a systemic approach to connect rural and urban areas: despite rural poverty being identified as one of the root causes for accelerated rural-urban migration and growth of slums in Africa, it is not addressed as an urban policy priority in the NUPs [42].

Table 1. Elements of generic and specific capacities related to informal settlements in the SDGs (Sustainable Development Goals), NUA (New Urban Agenda) and NUPs (New Urban Policies).

\begin{tabular}{|c|c|c|c|}
\hline & SDGs & NUA & NUPs \\
\hline Systemic view & $\begin{array}{c}\text { "Resilient and sustainable cities" } \\
\text { Balance between the dimensions of } \\
\text { sustainable development } \\
\text { Foster sustainable rural-urban } \\
\text { linkages and regional planning } \\
\text { (11.A) }\end{array}$ & $\begin{array}{l}\text { A paradigm shift towards a more } \\
\text { holistic view on urban issues } \\
\text { Understanding the "fundamental } \\
\text { drivers of change" } \\
\text { Creating integration, coherence } \\
\text { and predictability in urban } \\
\text { governance } \\
\text { "Strategies that go beyond } \\
\text { physical and environmental } \\
\text { improvements ... into social, } \\
\text { economic, cultural and political } \\
\text { dimensions" [14] }\end{array}$ & $\begin{array}{l}\text { Rapid urbanization and the } \\
\text { related growth of informal } \\
\text { settlements as the key challenges } \\
\text { Rural poverty identified as a } \\
\text { dominant factor pushing rapid } \\
\text { urbanization }\end{array}$ \\
\hline Generic capacities & $\begin{array}{c}\text { Slum upgrading, access to adequate } \\
\text { housing, basic services and } \\
\text { transportation (targets } 11.1,11.2) \\
\text { Transparent human settlement } \\
\text { planning (11.3) } \\
\text { Integrity of built environment (11.4, } \\
11.7,11.8,11 . C)\end{array}$ & $\begin{array}{l}\text { Slum upgrading and prevention } \\
\text { programmes: security of tenure, } \\
\text { lack of infrastructure, basic } \\
\text { services and poor-quality housing }\end{array}$ & $\begin{array}{c}\text { In-situ upgrading: "best practice" } \\
\text { to tackle with slums } \\
\text { Urban housing } \\
\text { Provision of basic services and } \\
\text { infrastructure } \\
\text { Poverty reduction and job creation } \\
\text { Land management [42] }\end{array}$ \\
\hline Specific capacities & $\begin{array}{l}\text { Disaster risk reduction strategies } \\
\qquad(11.6,11 . \mathrm{B})\end{array}$ & & \\
\hline
\end{tabular}

Indeed, overemphasizing upgrading as the dominant policy can be problematic. Despite evidence showing that the upgrading efforts have improved the day-to-day life of slum dwellers through secured tenure [67], participatory urban governance and empowerment [68] and investments in infrastructure [69], Archer [67] and Minnery et al. [70] conclude that the upgrading programs are feasible for a short-term physical uplift, while failing at pro-active long-term planning. Informal settlements and the preceding causes are rarely included in the discourse underlining the need to develop for more holistic approaches that connect different institutional and spatial scales $[4,13,29,54,70,71]$.

As we showed above, balance and synergies between different individual and system-wide generic and specific capacities are needed to pro-actively cope with acute emerging issues (such as rapid migration and the emergence of slums), alongside the chronic problem of overall sustainable development (Figure 3). We note that in their current state, urban initiatives emphasize generic capacities over specific ones, possibly causing "political inactivity, where local authorities tend to react to rhetoric rather than make meaningful responses" [31,53].

We argue that urban initiatives should promote human development in rural areas in order to slow down migration fluxes caused by urban primacy and prolonged rural-urban divide in terms of socio-economic development [50,72]. System-level capacity for regional planning and urban 
governance, especially, is pivotal in order to close the rural-urban gap (Figures 2 and 3). Moreover, in our view, system-level (e.g., governance) generic capacity should be highlighted in order to create specific coping strategies for in-migration, in order to prevent developments in which urban policies restrict migration by providing poor living conditions [73], and hence exacerbating the adverse effects instead of curbing them [9].

\subsection{Leverage of Cross-Cutting Domains for Sustainable Rural-Urban Dynamics: "Water in All Policies"}

Based on our review, it is evident that effective policy-making and sustainable urbanization desperately needs tools for systemic understanding the phenomenon. Policy-integration and creation of inter-sectoral synergies, i.e., the key elements of "governance for sustainability" [74], urgently call for novel and practical tools. The "in All Policies" approach presents one popular example in which so-called cross-cutting domains are used to screen public policies through a selected "lens" in order to achieve coherent policy integration [38]. For instance, the generic and specific capacities identified in our approach adhere to multiple fields of public policy such as natural resources management, education and health (Figure 2), which all share common nominators through which all fields can simultaneously be improved.

The "Water in All Policies" [15] approach uses water as the lens, given its imperative role in the sustainability and resilience of human-nature systems [75-77]. We propose the "water lens" approach for identifying leverage points for more synergistic and holistic urban policy-making, given that water-related vulnerabilities frame migration and the growth of informal settlements.

In Cambodia, water plays a central role in inducing rapid yet latent and unsustainable migration flows from rural Tonle Sap towards urban Phnom Penh [78]. In general, the environmental push factors of migration appear commonly as quantitative and qualitative water shortages, such as droughts and degradation, affecting crop productivity, agricultural practices, employment and rural income [12,79-81]. In Tonle Sap, sustainable management of local water resources is crucial in sustaining the pillars of SES, e.g., the ecosystem services, food security, traditional livelihoods and rural adaptive capacity [78,82-84]. In Mexico, prolonged droughts to be a primary driver for rural-urban migration [85], whereas sudden water extremes such as storms and floods are expected to be increasingly important drivers globally $[58,86]$. Drawing on both cases, we see that improved water management strategies would leverage not only decreased environmental vulnerability but also build multiple generic and specific socio-economic capacities, such as employment, which complement many environmental vulnerabilities as primary drivers for migration [50].

In the urban context, functioning water infrastructure, management schemes and prospects for higher adaptive capacity and resilience to hazards can function as attractions in urban areas [50,87]. However, many rapidly growing cities manifest low capacity and the lack of political will to adjust infrastructure according to growth. Indeed, good urban water management, including both physical and social water infrastructure, is simply one of the biggest challenges of the urbanizing world in the future [88] and it is generally agreed that the urban poor face multiple social vulnerabilities attached to water: vector-born diseases [89] and serious flood hazards [90] are among the most typical examples. In our view, urban water management has leverage to improve living conditions towards higher socio-economic sustainability, and vice versa.

For instance, in Phnom Penh, slum dwellers employed in the informal, low-skilled jobs were exposed to higher vulnerabilities caused by floods hazards, compared to those who were employed formally [90]. Meanwhile in Jakarta, Indonesia, low socio-economic development has resulted in reduced capacity of some slum dwellers to afford clean water or the knowledge about piped water quality [91]. While physical water infrastructure is one key element of the adaptive capacity in urban areas, we see that also "software" related to water infrastructure must be strengthened through socio-economic development.

To conclude, we see that screening public policies through water lens has high potential in identifying leverage points, as well as conflicts between institutional interests and respective outcomes 
in terms of rural and urban areas and policy coherence. The last-mentioned are pivotal in building adaptive capacity and resilience across the multiple dimensions of the social-ecological systems $[2,92,93]$.

\section{Ways Forward}

\subsection{From Adaptive Capacity to Mitigative Capacity?}

We have provided new insights into the challenge of informal settlements by identifying the components of rural-urban migration through the concept of adaptive capacity. Both generic and specific capacities materialize as crucial components behind the pushing and pulling factors of migration, as well as the outcomes and challenges of urbanization (Figures 2 and 3). We accord with recent literature, which suggest that among other challenges of urbanization, slums appear as a result of complex networks within and beyond urban areas, appointing numerous challenges for urban research and governance $[29,53,56,94]$. However, hitherto the urban challenges, such as the emergence of slums, have been studied mainly without considering the rural links to urbanization. We concur with previous research suggesting that system approaches are applicable to urban issues, given that they allow considering the non-linear dynamics of urbanization, and more importantly the sustainability of the system. While Eakin et al. [33] approached adaptive capacity from a climate adaptation perspective, it is clear that high generic and specific capacities across multiple organizational and individual levels in both rural and urban areas are a prerequisite for sustainable rural-urban migration. However, there are some limitations to this framework, which should be discussed.

Firstly, while socio-ecological approach is ideal for studying the linkages between social and ecological dimensions of complex urban systems, it gives little emphasis on technology and infrastructure, as well as other built environment, which are vital to the adaptive capacity and resilience of a SES [32,95]. Our study shows that development of technologies and infrastructure across the rural-urban transition is highly important in terms of building generic and further specific capacities. Development of skills is directly proportional to education and training in individual and organizational dimensions, while competence of a region can be enhanced by robust societal and physical infrastructure and governance. For instance, together with good managerial capacity, adequate infrastructure is needed to lift an economy from secondary to tertiary level [50] typically yielding positive socio-economic impacts through improved income and provision of basic services as we showed above. Thus, including social-technological networks in the future studies of complex urban systems is of primary importance.

Secondly, although adaptive capacity provides a feasible concept for exploring the sustainability of a rural-urban system, overemphasizing adaptiveness in terms of urbanization may be problematic. As a concept, adaptive capacity emerges from the fields of biology and ecology, which see adaptation as a reactive response to shocks and hazards [24]. This may reinforce the reactive responses to build physical and social capacity in vulnerable areas, while pro-active measures to mitigate and avoid the potential adverse effects of urbanization are largely absent in urban context. This is remarkable because urban social-ecological systems entail a strong social dimension that should reflect proactive and conscious actors, unlike the ecological dimension which reflects naturally more reactive and passive agents.

In fact, to shift the discussion from adaptation to mitigation, climate change scholarship has established the concept of mitigative capacity which depicts the ability to reduce emissions $[92,96]$. However, in low-income countries, pro-active and integrative policies are rare, especially due to political inability and unwillingness $[74,96]$. This implies the need for systematic capacity building by governments in order for mainstream mitigation to be made a policy priority for sustainable urbanization. Moreover, sustainable implementation of any policy, be it reactive or pro-active by nature, requires strong individual and communal capacity. For instance, sufficient education is a prerequisite for both adaptation and mitigation at the grassroots. Finally, while adaptation is essential 
for coping with the myriad of existing urban challenges, urban research and policy-making should adopt the concept of mitigative capacity more systematically in order to reduce future challenges.

\subsection{Insights from the Water Sector}

Even though water has been identified as one of the most important challenges of urbanizing world [88], the role of water in the sustainability of a rural-urban SES has not been studied systemically. In this review, we put forward the discussion around systemic policy-making in sustainable urban development by exploring the potential of one critical cross-cutting domain, water. Our analysis showed that the diverging ecological and social facets of water appears as key elements under most pushing and pulling factors, and can function as a catalyst or restriction behind the social and physical capacities that contribute to the outcomes of migration.

Indeed, water is acknowledged as a key element in multiple fields of public policy, which govern the conditions for sustainable migration. Level of overall human development $[18,97]$, rural development and agriculture [98,99], urban development and water management [88] are few of the many examples. We argue that underpinning healthy and sustainable water system as a policy priority and common objective in all policies within a rural-urban SES has potential not only in fostering development in rural and urban areas in their own right, but also in creating pro-active policy synergies and coherence regarding urban challenges.

Kemp et al. [74] suggest that along with commonly set objectives, mutually agreed indicators are essential for measuring progress in terms of sustainability. Currently, the SDGs are the most popular set of global indicators for sustainability, including urban sustainability (SDG11) [13]. However, our synthesis shows that the goals do not intrinsically draw a systemic view of urban sustainability and the root causes behind the challenges. SDGs have also been criticized for being too many (17 goals and 169 targets) and thus unwieldy to monitor $[98,100]$, and further for relying too much on an optimistic spirit [101]. In fact, Nilsson et al. [102] also highlight the need to "map the interactions between Sustainable Development Goals" in order to identify synergies and trade-offs between the goals.

We agree with Nilsson et al. [102] and a concurrent analogy suggesting that in order to measure sustainability holistically, the SDGs should be seen as a Rubik's cube: to solve the puzzle, one needs to consider all corners and faces [103]. Here the use of the "in all policies" approach has high potential, drawing attention from individual goals to wider interlinked systems. In this puzzle, the urban goal is only one of the many pieces, which depend on each other: Social development, energy production, sustainable ecosystem, migration and slum dwellers are interdependent through complex networks within complex social-ecological systems, as we have shown. Cross-cutting goals, including water, may provide a feasible tool for identifying synergies in the puzzle. For instance, Pradhan et al. [104] and McCollum et al. [39] show that poverty reduction and health, affordable and green energy and water and sanitation are the keys for achieving the majority of other SDGs, while the United Nations [97] acknowledges the SDG6 as a prerequisite for solving all other goals. Clearly, water provides one bridge over the gap between social and ecological subsystems by connecting many physical and social elements, such as infrastructure, gender equality and basic education [105]. These findings support the idea of leveraging cross-cutting domains for holistic urban policies and sustainable outcomes.

\section{Conclusions}

Urbanization is a phenomenon where the excessive complexity and dimension of problems should not hamper action but instead, actions should be encouraged and enabled with synergistic and integrative pathways for urban sustainability. This overview has provided a novel conceptualization of slums by incorporating a socio-ecological system framework with an emphasis on adaptive capacity. Further, it has advanced the discussion around synergistic and coherent policy-making in the urban context by exploring the concept of cross-cutting domains.

Firstly, this study shows that while current literature frames migration to urban areas as an efficient adaptation method for multiple socio-ecological deficiencies in rural development, the sustainability of 
such adaptation pathways has not been studied sufficiently. We highlight that exploring the interplay of different components of adaptive capacity is feasible for conceptualizing such a multi-dimensional phenomenon. Moreover, social-technical networks, including physical built environments, should be consciously underlined: while SES is applicable for analysis of complex urban systems, it does not naturally emphasize the importance of a physical built environment, which is crucial to urban development and adaptive capacity. More case-specific studies are needed in order to illustrate the variety and sensitivity of the studied problematics in policy-making and practice.

Secondly, we emphasize that mitigation and pro-active strategies should be highlighted in urban agendas and policies in order to reduce the emergence of urban challenges. We show that cross-cutting domains may provide prominent tools to identify synergies and causalities between the social and ecological dimensions, yielding important consolidating possibilities and leveraging pro-active policy design and implementation. The role and value of the cross-cutting domains of complex rural-urban systems should be further investigated and discussed among researchers and practitioners.

Author Contributions: The authors have contributed to the study accordingly: Conceptualization, V.N., M.T. and O.V.; methodology V.N., M.T. and O.V.; formal analysis, V.N.; data curation, V.N.; writing-original draft preparation, V.N.; writing-review and editing, all; visualization, V.N. and M.T.; supervision, M.T. and O.V.; project administration, V.N.; funding acquisition, O.V.

Funding: This research was funded by Maa-ja Vesitekniikan Tuki ry. through Majakka project and Aalto University.

Acknowledgments: We thank the Water and Development Research Group for support and inspiration, and anonymous referees for their comments.

Conflicts of Interest: The authors declare no conflicts of interest. The funders had no role in the design of the study; in the collection, analyses, or interpretation of data; in the writing of the manuscript, or in the decision to publish the results.

\section{References}

1. United Nations. Millennium Development Goals Database. Available online: http://mdgs.un.org/unsd/mdg/ default.aspx (accessed on 21 May 2019).

2. Acuto, M.; Parnell, S.; Seto, K.C. Building a global urban science. Nat. Sustain. 2018, 1, 2-4. [CrossRef]

3. UN Habitat. Habitat III issue Papers: 22 - Informal Settlements. Available online: https://unhabitat.org/ habitat-iii-issue-papers-22-informal-settlements/ (accessed on 21 May 2019).

4. UN Habitat. World Cities Report 2016: Urbanization and Development-Emerging Futures; UN-Habitat: Nairobi, Kenya, 2016; p. 262.

5. United Nations. Universal Declaration of Human Rights; United Nations: Paris, France, 1948.

6. United Nations. The Human Right to Water and Sanitation; A/RES/64/292; United Nations: New York, NY, USA, 2010.

7. Rana, M.P. Urbanization and sustainability: Challenges and strategies for sustainable urban development in Bangladesh. Environ. Dev. Sustain. 2011, 13, 237-256. [CrossRef]

8. Roy, D.; Lees, M.H.; Palavalli, B.; Pfeffer, K.; Sloot, M.A.P. The emergence of slums: A contemporary view on simulation models. Environ. Model. Softw. 2014, 59, 76-90. [CrossRef]

9. Tacoli, C.; Mcgranahan, G.; Satterthwaite, D. Urbanization, Rural-Urban Migration and Urban Poverty; IIED Working Paper; Human Settlements Group, International Institute for Environment and Development: London, UK, 2015.

10. Mahabir, R.; Crooks, A.; Croitoru, A.; Agouris, P. The study of slums as social and physical constructs: Challenges and emerging research opportunities. Reg. Stud. Reg. Sci. 2016, 3, 399-419. [CrossRef]

11. Paterson, W.; Rushforth, R.; Ruddell, B.L.; Konar, M.; Ahams, I.C.; Gironás, J.; Mijic, A.; Mejia, A. Water Footprint of Cities: A Review and Suggestions for Future Research. Sustainability 2015, 7, 8461-8490. [CrossRef]

12. Black, R.; Bennett, S.R.G.; Thomas, S.M.; Beddington, J.R. Migration as adaptation. Nature 2011, 478, 447-449. [CrossRef] [PubMed]

13. United Nations. Transforming Our World: The 2030 Agenda for Sustainable Development. Available online: https://www.un.org/ga/search/view_doc.asp?symbol=A/RES/70/1\&Lang=E (accessed on 21 May 2019). 
14. United Nations. New Urban Agenda; United Nations: New York, NY, USA, 2017.

15. Varis, O.; Enckell, K.; Keskinen, M. Integrated water resources management: Horizontal and vertical explorations and the "water in all policies" approach. Int. J. Water Resour. Dev. 2014, 30, 433-444. [CrossRef]

16. Rockström, J.; Steffen, W.; Noone, K.; Persson, Å.; Chapin, F.S., 3rd; Lambin, E.F.; Lenton, T.M.; Scheffer, M.; Folke, C.; Schellnhuber, H.J.; et al. A safe operating space for humanity. Nature 2009, 461, 472-475. [CrossRef]

17. Zhang, Q.; Prouty, C.; Zimmerman, J.B.; Mihelcic, J.R. More than Target 6.3: A Systems Approach to Rethinking Sustainable Development Goals in a Resource-Scarce World. Engineering 2016, 2, 481-489. [CrossRef]

18. Mehta, L. Water and Human Development. World Dev. 2014, 59, 59-69. [CrossRef]

19. Green, B.N.; Johnson, C.D.; Adams, A. Writing narrative literature reviews for peer-reviewed journals: Secrets of the trade. J. Chiropr. Med. 2006, 5, 101-117. [CrossRef]

20. Gallopín, G.C. Human dimensions of global change: Linking the global and the local processes. Int. Soc. Sci. J. 1991, 43, 707-718.

21. Adger, W.N. Vulnerability. Glob. Environ. Chang. 2006, 16, 268-281. [CrossRef]

22. Berkes, F.; Folke, C. Linking social and ecological systems for resilience and sustainability. In Linking Social and Ecological Systems: Management Practices and Social Mechanisms for Building Resilience; Berkes, F., Folke, C., Eds.; Cambridge University Press: Cambridge, UK, 1998; pp. 1-15, ISBN 0-521-78562-6.

23. Janssen, M.A.; Ostrom, E. Resilience, vulnerability, and adaptation: A cross-cutting theme of the International Human Dimensions Programme on Global Environmental Change. Glob. Environ. Chang. 2006, 16, 237-239. [CrossRef]

24. Engle, N.L. Adaptive capacity and its assessment. Glob. Environ. Chang. 2011, 21, 647-656. [CrossRef]

25. Folke, C. Resilience: The emergence of a perspective for social-ecological systems analyses. Glob. Environ. Chang. 2006, 16, 253-267. [CrossRef]

26. Hinkel, J. "Indicators of vulnerability and adaptive capacity": Towards a clarification of the science-policy interface. Glob. Environ. Chang. 2011, 21, 198-208. [CrossRef]

27. Ostrom, E. A general framework for analyzing sustainability of social-ecological systems. Science 2009, 325, 419-422. [CrossRef]

28. Bai, X.; Schandl, H. Urban ecology and industrial ecology. In The Routledge Handbook of Urban Ecology; Douglas, I., Goode, D., Houck, M., Wang, R., Eds.; Routledge: Abingdon, UK, 2010; pp. 26-37, ISBN 978-0-415-49813-5.

29. Bai, X.; Surveyer, A.; Elmqvist, T.; Gatzweiler, F.W.; Güneralp, B.; Parnell, S.; Prieur-Richard, A.-H.; Shrivastava, P.; Siri, J.G.; Stafford-Smith, M.; et al. Defining and advancing a systems approach for sustainable cities. Curr. Opin. Environ. Sustain. 2016, 23, 69-78. [CrossRef]

30. Schandl, H.; Capon, A. Cities as social-ecological systems: Linking metabolism, wellbeing and human health. Curr. Opin. Environ. Sustain. 2012, 4, 375-377. [CrossRef]

31. Schandl, H.; Boyden, S.; Hosking, K. 'Biosensitive' cities-A conceptual framework for integrative understanding of the health of people and planetary ecosystems. Curr. Opin. Environ. Sustain. 2012, 4, 378-384. [CrossRef]

32. Meerow, S.; Newell, J.P.; Stults, M. Defining urban resilience: A review. Landsc. Urban Plan. 2016, 147, 38-49. [CrossRef]

33. Eakin, H.C.; Lemos, M.C.; Nelson, D.R. Differentiating capacities as a means to sustainable climate change adaptation. Glob. Environ. Chang. 2014, 27, 1-8. [CrossRef]

34. Smit, B.; Wandel, J. Adaptation, adaptive capacity and vulnerability. Glob. Environ. Chang. 2006, 16, $282-292$. [CrossRef]

35. Turner, B.L.; Kasperson, R.E.; Matson, P.A.; McCarthy, J.J.; Corell, R.W.; Christensen, L.; Eckley, N.; Kasperson, J.X.; Luers, A.; Martello, M.L.; et al. A framework for vulnerability analysis in sustainability science. Proc. Natl. Acad. Sci. USA 2003, 100, 8074-8079. [CrossRef] [PubMed]

36. Lenton, R.; Muller, M. Integrated Water Resources Management in Practice: Better Water Management for Development, 1st ed.; Routledge: London, UK, 2012; ISBN 978-1-84977-174-0.

37. Hoff, H. Understanding the Nexus. Background Paper for the Bonn2011 Nexus Conference; Stockholm Environment Institute: Stockholm, Sweden, 2011; pp. 1-52. 
38. Leppo, K.; Ollila, E.; Pena, S.; Wismar, M.; Cook, S. Health in All Policies: Seizing Opportunities, Implementing Policies; Leppo, K., Ollila, E., Pena, S., Wismar, M., Cook, S., Eds.; Ministry of Social Affairs and Health: Helsinki, Finland, 2013; ISBN 978-952-00-3407-8.

39. McCollum, D.L.; Echeverri, L.G.; Busch, S.; Pachauri, S.; Parkinson, S.; Rogelj, J.; Krey, V.; Minx, J.C.; Nilsson, M.; Stevance, A.-S.; et al. Connecting the sustainable development goals by their energy inter-linkages. Environ. Res. Lett. 2018, 13, 033006. [CrossRef]

40. World Health Organization. Health in All Policies: Helsinki Statement, Framework for Country Action; World Health Organization: Geneva, Switzerland, 2014; ISBN 978-92-4-150690-8.

41. Biswas, A.K.; Udisha, S.; Tortajada, C. India's rural-urban conundrum-Get smart to revitalise rural regions. Available online: https://www.policyforum.net/indias-rural-urban-conundrum (accessed on 12 September 2017).

42. UN Habitat; OECD. Global State of National Urban Policy; UN Habitat: Nairobi, Kenya, 2018; ISBN 978-92-64-29074-7.

43. Eakin, H.; Lemos, M.C. Adaptation and the state: Latin America and the challenge of capacity-building under globalization. Glob. Environ. Chang. 2006, 16, 7-18. [CrossRef]

44. Du, Y.; Park, A.; Wang, S. Migration and rural poverty in China. J. Comp. Econ. 2005, 33, 688-709. [CrossRef]

45. Jedwab, R.; Christiaensen, L.; Gindelsky, M. Demography, urbanization and development: Rural push, urban pull and ... urban push? J. Urban Econ. 2017, 98, 6-16. [CrossRef]

46. Sridhar, K.S.; Reddy, A.V.; Srinath, P. Is it Push or Pull? Recent Evidence from Migration into Bangalore, India. J. Int. Migr. Integr. 2012, 14, 287-306. [CrossRef]

47. Harris, J.R.; Todaro, M.P. Migration, Unemployment and Developmnent: A Two-Sector Analysis. Am. Econ. Rev. 1970, 60, 126-142.

48. Henderson, J.V. Urbanization in a developing country. J. Dev. Econ. 1986, 22, 269-293. [CrossRef]

49. World Economic Forum. Migration and Its Impact on Cities. Geneva, Switzerland, 2017; p. 172. Available online: http://www3.weforum.org/docs/Migration_Impact_Cities_report_2017_HR.pdf (accessed on 21 May 2019).

50. Seto, K.C. Exploring the dynamics of migration to mega-delta cities in Asia and Africa: Contemporary drivers and future scenarios. Glob. Environ. Chang. 2011, 21, S94-S107. [CrossRef]

51. Black, R.; Adger, W.N.; Arnell, N.W.; Geddes, A.; Thomas, D. The effect of environmental change on human migration. Glob. Environ. Chang. 2011, 21, S3-S11. [CrossRef]

52. Fields, G.S. Rural-urban migration, urban unemployment and underemployment, and job-search activity in LDCs. J. Dev. Econ. 1975, 2, 165-187. [CrossRef]

53. Bai, X.; McAllister, R.R.; Beaty, R.M.; Taylor, B. Urban policy and governance in a global environment: Complex systems, scale mismatches and public participation. Curr. Opin. Environ. Sustain. 2010, 2, 129-135. [CrossRef]

54. UN Habitat. Habitat III issue Papers: 10 - Urban-Rural Linkages. Available online: http://habitat3.org/wpcontent/uploads/Habitat-III-Issue-Paper-10_Urban-Rural-Linkages-2.0.pdf (accessed on 21 May 2019).

55. Lemos, M.C.; Lo, Y.-J.; Nelson, D.R.; Eakin, H.; Bedran-Martins, A.M. Linking development to climate adaptation: Leveraging generic and specific capacities to reduce vulnerability to drought in NE Brazil. Glob. Environ. Chang. 2016, 39, 170-179. [CrossRef]

56. Ooi, G.L. Challenges of sustainability for Asian urbanisation. Curr. Opin. Environ. Sustain. 2009, 1, $187-191$. [CrossRef]

57. Ooi, G.L.; Phua, K.H. Urbanization and slum formation. J. Urban Health 2007, 84, 27-34. [CrossRef]

58. Adamo, S.B. Environmental migration and cities in the context of global environmental change. Curr. Opin. Environ. Sustain. 2010, 2, 161-165. [CrossRef]

59. Clark, W.A.V.; Lisowski, W. Prospect theory and the decision to move or stay. Proc. Natl. Acad. Sci. USA 2017, 114, E7432-E7440. [CrossRef]

60. Kahneman, D.; Tversky, A. Prospect Theory: An Analysis of Decision Under Risk. Econometrica 1979, 47, 263-292. [CrossRef]

61. Tversky, A.; Kahneman, D. Advances in Prospect Theory: Cumulative Representation of Uncertainty. J. Risk Uncertain. 1992, 5, 297-323. [CrossRef]

62. United Nations. The Sustainable Development Goals Report 2018; The United Nations: New York, NY, USA, 2018. 
63. Hajer, M.; Nilsson, M.; Raworth, K.; Bakker, P.; Berkhout, F.; De Boer, Y.; Rockström, J.; Ludwig, K.; Kok, M. Beyond Cockpit-ism: Four Insights to Enhance the Transformative Potential of the Sustainable Development Goals. Sustainability 2015, 7, 1651-1660. [CrossRef]

64. Patel, K. A successful slum upgrade in Durban: A case of formal change and informal continuity. Habitat Int. 2013, 40, 211-217. [CrossRef]

65. Kaika, M. 'Don't call me resilient again!': The New Urban Agenda as immunology ... or ... what happens when communities refuse to be vaccinated with 'smart cities' and indicators. Environ. Urban 2017, 29, 89-102. [CrossRef]

66. Garschagen, M.; Porter, L. The New Urban Agenda: From Vision to Policy and Action. Plan. Theory Pract. 2018, 19, 117-137. [CrossRef]

67. Archer, D. Baan Mankong participatory slum upgrading in Bangkok, Thailand: Community perceptions of outcomes and security of tenure. Habitat Int. 2012, 36, 178-184. [CrossRef]

68. Muchadenyika, D. Slum upgrading and inclusive municipal governance in Harare, Zimbabwe: New perspectives for the urban poor. Habitat Int. 2015, 48, 1-10. [CrossRef]

69. Gulyani, S.; Bassett, E.M. Retrieving the Baby from the Bathwater: Slum Upgrading in Sub-Saharan Africa. Environ. Plan. C Gov. Policy 2007, 25, 486-515. [CrossRef]

70. Minnery, J.; Argo, T.; Winarso, H.; Hau, D.; Veneracion, C.C.; Forbes, D.; Childs, I. Slum upgrading and urban governance: Case studies in three South East Asian cities. Habitat Int. 2013, 39, 162-169. [CrossRef]

71. Wolfram, M.; Maschmeyer, S. Cities, systems and sustainability: Status and perspectives of research on urban transformations. Curr. Opin. Environ. Sustain. 2016, 22, 18-25. [CrossRef]

72. Tacoli, C. Not Only Climate Change: Mobility, Vulnerability and Socio-Economic Transformations in Environmentally Fragile Areas of Bolivia, Senegal and Tanzania; Human Settlements Working Paper Series: Rural-Urban Interactions and Livelihood Strategies - 28; International Institute for Environment and Development: London, UK, 2011.

73. Henderson, J.V. Cities and Development. J. Reg. Sci. 2010, 50, 515-540. [CrossRef]

74. Kemp, R.; Parto, S.; Gibson, R. Governance for sustainable development: Moving from theory to practice. Int. J. Sustain. Dev. 2005, 8, 12-30. [CrossRef]

75. Folke, C. Freshwater for resilience: A shift in thinking. Philos. Trans. R. Soc. Lond. Ser. B Biol. Sci. 2003, 358, 2027-2036. [CrossRef]

76. Ripl, W. Water: The bloodstream of the biosphere. Philos. Trans. R. Soc. Lond. Ser. B Biol. Sci. 2003, 358, 1921-1934. [CrossRef]

77. Rockström, J.; Falkenmark, M.; Allan, T.; Folke, C.; Gordon, L.; Jägerskog, A.; Kummu, M.; Lannerstad, M.; Meybeck, M.; Molden, D.; et al. The unfolding water drama in the Anthropocene: Towards a resilience based perspective on water for global sustainability. Ecohydrology 2014, 7, 1249-1261. [CrossRef]

78. Heinonen, U. Environmental Impact on Migration in Cambodia: Water-related Migration from the Tonle Sap Lake Region. Int. J. Water Resour. Dev. 2006, 22, 449-462. [CrossRef]

79. Barrios, S.; Bertinelli, L.; Strobl, E. Climatic change and rural-urban migration: The case of sub-Saharan Africa. J. Urban Econ. 2006, 60, 357-371. [CrossRef]

80. Adger, W.N.; Arnell, N.W.; Black, R.; Dercon, S.; Geddes, A.; Thomas, D.S.G. Focus on environmental risks and migration: Causes and consequences. Environ. Res. Lett. 2015, 10, 060201. [CrossRef]

81. Nawrotzki, R.J.; Hunter, L.M.; Runfola, D.M.; Riosmena, F. Climate change as a migration driver from rural and urban Mexico. Environ. Res. Lett. 2015, 10, 114023. [CrossRef]

82. Nuorteva, P.; Keskinen, M.; Varis, O. Water, livelihoods and climate change adaptation in the Tonle Sap Lake area, Cambodia: Learning from the past to understand the future. J. Water Clim. Chang. 2010, 1, 87-101. [CrossRef]

83. Keskinen, M.; Someth, P.; Salmivaara, A.; Kummu, M.; Keskinen, M.; Someth, P.; Salmivaara, A.; Kummu, M. Water-Energy-Food Nexus in a Transboundary River Basin: The Case of Tonle Sap Lake, Mekong River Basin. Water 2015, 7, 5416-5436. [CrossRef]

84. Salmivaara, A.; Kummu, M.; Varis, O.; Keskinen, M. Socio-Economic Changes in Cambodia's Unique Tonle Sap Lake Area: A Spatial Approach. Appl. Spat. Anal. Policy 2016, 9, 413-432. [CrossRef]

85. Nawrotzki, R.J.; DeWaard, J.; Bakhtsiyarava, M.; Ha, J.T. Climate shocks and rural-urban migration in Mexico: Exploring nonlinearities and thresholds. Clim. Chang. 2017, 140, 243-258. [CrossRef] 
86. Warner, K. Global environmental change and migration: Governance challenges. Glob. Environ. Chang. 2010, 20, 402-413. [CrossRef]

87. Ernstson, H.; van der Leeuw, S.E.; Redman, C.L.; Meffert, D.J.; Davis, G.; Alfsen, C.; Elmqvist, T. Urban Transitions: On Urban Resilience and Human-Dominated Ecosystems. AMBIO 2010, 39, 531-545. [CrossRef]

88. Larsen, T.A.; Hoffmann, S.; Lüthi, C.; Truffer, B.; Maurer, M. Emerging solutions to the water challenges of an urbanizing world. Science 2016, 352, 928-933. [CrossRef]

89. Costello, A.; Abbas, M.; Allen, A.; Ball, S.; Bell, S.; Bellamy, R.; Friel, S.; Groce, N.; Johnson, A.; Kett, M.; et al. Managing the health effects of climate change: Lancet and University College London Institute for Global Health Commission. Lancet 2009, 373, 1693-1733. [CrossRef]

90. Flower, B.; Fortnam, M.; Kol, L.; Sasin, P.; Godfrey, R. Using participatory methods to uncover interacting urban risks: A case study of three informal settlements in Phnom Penh, Cambodia. Environ. Urban 2017, 30, 301-316. [CrossRef]

91. Walter, C.T.; Kooy, M.; Prabaharyaka, I. The role of bottled drinking water in achieving SDG 6.1: An analysis of affordability and equity from Jakarta, Indonesia. J. Water Sanit. Hyg. Dev. 2017, 7, 642-650. [CrossRef]

92. Folke, C.; Carpenter, S.; Elmqvist, T.; Gunderson, L.; Holling, C.; Walker, B. Resilience and Sustainable Development: Building Adaptive Capacity in a World of Transformations. AMBIO 2002, 31, 437-440. [CrossRef]

93. Pahl-Wostl, C. A conceptual framework for analysing adaptive capacity and multi-level learning processes in resource governance regimes. Glob. Environ. Chang. 2009, 19, 354-365. [CrossRef]

94. Bai, X.; Dawson, R.J.; Ürge-Vorsatz, D.; Delgado, G.C.; Salisu Barau, A.; Dhakal, S.; Dodman, D.; Leonardsen, L.; Masson-Delmotte, V.; Roberts, D.C.; et al. Six research priorities for cities and climate change. Nature 2018, 555, 23-25. [CrossRef]

95. Smith, A.; Stirling, A. The Politics of Social-ecological Resilience and Sustainable Socio- technical Transitions. Ecol. Soc. 2010, 15, 11. Available online: http://www.ecologyandsociety.org/vol15/iss1/art11/ (accessed on 21 May 2019). [CrossRef]

96. Winkler, H.; Baumert, K.; Blanchard, O.; Burch, S.; Robinson, J. What factors influence mitigative capacity? Energy Policy 2007, 35, 692-703. [CrossRef]

97. United Nations. Sustainable Development Goal 6: Synthesis Report on Water and Sanitation; UN Water: New York, NY, USA, 2018.

98. Wrathall, D.J.; Van Den Hoek, J.; Walters, A.; Devenish, A. Water Stress and Human Migration: A Global, Georeferenced Review of Empirical Research; Food and Agriculture Organization of the United Nations: Rome, Italy, 2018; ISBN 978-92-5-130426-6.

99. FAO; IFAD; IOM; WFP. The Linkages between Migration, Agriculture, Food Security and Rural Development; Technical Report; FAO; IFAD; IOM; WFP: Rome, Italy, 2018; ISBN 978-92-5-130832-5.

100. Kumar, S.; Kumar, N.; Vivekadhish, S. Millennium Development Goals (MDGs) to Sustainable Development Goals (SDGs): Addressing Unfinished Agenda and Strengthening Sustainable Development and Partnership. Indian J. Community Med. 2016, 41, 1-4. [CrossRef]

101. Gupta, J.; Vegelin, C. Sustainable development goals and inclusive development. Int. Environ. Agreem. 2016, 16, 433-448. [CrossRef]

102. Nilsson, M.; Griggs, D.; Visbeck, M. Policy: Map the interactions between Sustainable Development Goals. Nature 2016, 534, 320-322. [CrossRef]

103. Stucki, V.; Wegerich, K.; Rahaman, M.M.; Varis, O. Introduction: Water and Security in Central Asia-Solving a Rubik's Cube. Int. J. Water Resour. Dev. 2012, 28, 395-397. [CrossRef]

104. Pradhan, P.; Costa, L.; Rybski, D.; Lucht, W.; Kropp, J.P. A Systematic Study of Sustainable Development Goal (SDG) Interactions. Earth Future 2017, 5, 1169-1179. [CrossRef]

105. Jasper, C.; Le, T.-T.; Bartram, J. Water and sanitation in schools: A systematic review of the health and educational outcomes. Int. J. Environ. Res. Public Health 2012, 9, 2772-2787. [CrossRef]

(C) 2019 by the authors. Licensee MDPI, Basel, Switzerland. This article is an open access article distributed under the terms and conditions of the Creative Commons Attribution (CC BY) license (http://creativecommons.org/licenses/by/4.0/). 